
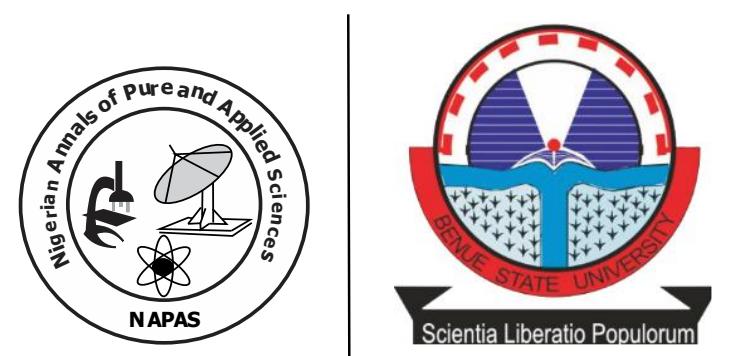

\title{
Relationship between Rainfall, Surface Runoff and Soil Loss on an Experimental Farm in the Middle Belt of Nigeria
}

\author{
Aper, J. A., * lorkua, S.A and Akegh, N. J. \\ Department of Geography \\ Benue State University, Makurdi, Nigeria \\ *corresponding author: jimaper@yahoo.com +2348080815988
}

\begin{abstract}
Rainfall induced depletion of soil nutrients resulting from runoff and soil erosion are a main threat for agricultural lands, tending to reducing soil fertility, soil productivity and eventually leading to the un-sustainability of agricultural production systems. It is based on the problems associated with soil loss that the required mulch type, mulch cover and slope of the farming field need to be properly investigated and determined. This research therefore analyzed surface runoff and soil loss under different mulch treatment at a farm site in Benue State, in the middle-belt region of Nigeria. The main aim is to analyze the effect of varied mulching will have on runoff and soil loss volumes resulting from rainfall and examine the implication of the results on soil management practice in the region. Experimental plots of $20 \mathrm{~m}$ long by $3 \mathrm{~m}$ wide were carved out with an outlet down slope of $1.5 \mathrm{~m}^{2}\left(20 \mathrm{~m} \times 3 \mathrm{~m}+1.5 \mathrm{~m}^{2}=61.5 \mathrm{~m}^{2}\right)$ were bordered with corrugated iron sheets and inserted with runoff and soil loss receptors. The experimental plots were treated with weighted organic materials (mulching, in tons) and planted with maize with plots of zero (0) tons as control (T1). The maize planted was spaced $25 \mathrm{~cm}$ on row and $75 \mathrm{~cm}$ on columns. The experimental plots were replicated and symbolized as $(\mathrm{T} 1)=$ bare surface $(0$ tons $\mathrm{A}, \mathrm{B}$ and C), (T2) = surface mulch +maize (4 tons A, B and C) and (T3)= surface mulch + maize (8 tons A, B and C). Rainfall data was collected over ten (10) rain events and runoff and soil loss measurements was analyzed with using correlation statistics, variability and regression. The results show that $96.14 \%$ runoff occurs on T1, 3.22\% and $0.63 \%$ runs off on the T2 and T3 respectively with corresponding $193.7 \mathrm{~kg}, 3.1 \mathrm{~kg}$ and $0.5 \mathrm{~kg}$ soil loss. The study finds out that mulching reduces simultaneously both runoff and soil loss in the region. The amount rainfall only has no significant effect on amount of runoff and volume of soil loss. The study revealed that, surface cover combined with simple cropping controls runoff and soil loss by $67 \%$ and $61 \%$ respectively. This will be useful to farmers in addition to the fact that mulching also has a collateral benefit of stimulating microbial activities and regulating soil moisture and temperature.
\end{abstract}

Key words: mulching treatment, surface runoffs, soil loss, middle belt Nigeria. 


\section{Introduction}

Rainfall is an important climatic element responsible for soil and nutrients losses which are a major threat to agricultural soils leading to the un-sustainability of agricultural production systems in the tropics (Montenegro, et al, 2013). Erosion is a natural process, but it has been increased dramatically by human land use, especially industrial, agriculture, deforestation, and urban sprawl. Land that is used for conservational agriculture generally experiences a significantly greater rate of erosion than that of land under natural vegetation, or land used for sustainable agricultural practices. The poor protection offered against raindrop impact by a sparse crop cover is a major factor contributing to severe splash erosion, which is a major process in providing detached soil particles for transport by overland flow (Iorkua, 2013). It is based on the problems associated with soil loss that the required mulch type, mulch cover and slope of the farming field need to be determined. This, in effect, may reduce surface runoff and increase infiltration of water into the soil and may also reduce the depletion of water within the root zone.

A study of effect of rainfall on surface runoff and soil loss was done by Jordan, Zavala and Gil, (2010) in Spain, using single mulch material to assess the effect on soil properties and runoff. Also Jin and Cornelis (2009) studied the effect of residue cover and rainfall intensity on runoff and soil organic carbon losses; Ghalomi and Homaee (2013), carried out experiment using straw mulch on splash erosion and sediment yield in Iran, while, Uwah and Iwo (2011) examined the effectiveness of organic mulch on the productivity of maize and weed growth in the south-south zone (Calabar) in Nigeria, whereas, Iorkua, (2013),within the middle belt of Nigeria (Benue) assessed the effect of mulching (dead organic materials) on splash erosion. Most of these studies were carried out using single mulch material except Iorkua, (2013) who used four (4) mulch materials on varied slope angles. Dugeri, (2007), used micro plots with different mulch materials on runoff yield in Benue State University Makurdi. The study inclined on runoff and sediment yield. But still, there is a pending knowledge (gap) on surface runoff and soil loss within middle belt of Nigeria, where there is a basic occupation (farming agriculture) whose main source of water is the natural rainfall.
In Benue state, where virtually all agricultural activities are dependent on natural rainfall which experiences a high erosion problems, where bare soil conditions usually occur during the dry spell, particularly at rain-fed (non-irrigated) plots, high-intensity rainfall events can produce large surface water discharge which will lead to soil loss rates and long-term land degradation. Therefore, the use of rainfall parameters at treated plot scales can allow performance evaluation of conservation techniques such as mulching with cereals crop (planted maize) to check runoff and soil losses. The present research is aimed at the analysis of surface runoff and soil loss under different level of mulch cover materials.

The aim of the study is to carry out analysis of surface runoff and soil loss under different levels of mulch materials in part of Middle-Belt of Nigeria. This is with the view to determine the effect of mulch materials on the volume of runoff and soil loss in the study area To determine the effect of rainfall amount on runoff and soil loss in the study area, to establish the relationship between rainfall and mulching on runoff amount and soil loss under different mulch treatments, to examine the implication of mulching on soil management techniques in the study area.

This research is significant in diverse ways; at the end of this study, it will add to existing literature in the field of academics; it will also serve as an eye opener to Agriculturist on soil management techniques to conserve soil and water on farm fields. It will serve as road map in decision making to the government and planners in executing policies. In the academic line, it is significant because it will boost the literature. The study will be a reference point concerning quest for knowledge, in fields like, soil engineers/scientist, crop production and management, a rural geographer, a geomorphologist and host of others. Also it will be as a bridge of knowledge within the middle belt of Nigeria especially Benue state where less has been researched in this discipline. To an Agriculturist, there is need to understand a particular type of land (soil) under cultivation and to choose the appropriate farming techniques to suit the crop which will lower down the negative effect of the soil on crops. Unger and Jones, (1981) argued that mulching is one of the management practices for increasing water use 
efficiency and weed control in crop fields. To government and other policy makers, it will make use of the study as a base reference while taking a decision concerning soil management within a similar soil type. For instance, contractors charge with construction of road can fall back to seek information on that particular area. In view of the above, the research will be of immense importance to the mentioned above and who-soever may found it useful.

\section{Materials and Methods Study Area}

The study was carried out within the teaching and research farm of the College of Agronomy, University of Agriculture in Makurdi town (Figure 1). Makurdi is located between latitudes $7^{\circ} \quad 41^{\prime} \mathrm{N}$ and $7^{\circ} 42^{\prime} \mathrm{N}$ and between longitudes $8^{\circ} 27^{\prime} \mathrm{E}$ and $8^{\circ} 28^{\prime} \mathrm{E}$, at an elevation of $97 \mathrm{~m}$ asl with mean slope of $4 \%$ on average. The University is bounded in the north by Agan Toll Gate and Tse-Origbo village, north-east by TseTyodugh, south-east by Tse-Chagu and south- south by River Benue and to the west by Pila village. The farm is situated within the flood plains of River Benue in Makurdi, Benue State. Makurdi is overlain by the albian shales. It consists of a thick mass of current bedded coarsely grained, deposits known as Makurdi sandstones (Abaa, 2004) ocuring sometimes unconformably intermixed with deposits of thick marine, dark, grey shale, siltstone and subordinate limestone under the basement complex rocks ((Iorliam, Agbede, and Joel 2012).

The dominant soils is the tropical ferruginous which is rich in oxides and hydroxides of iron (fe) and aluminum (al) (Nyagba, 1995). The tropical ferruginous soils associated with the savannah are derived mainly from the basement complex and old sedimentary rocks, and are red, yellow or brown in colour (Areola 1983). The soil profile range from $0-45 \mathrm{~cm}$ deep and the soil is sandyclay-loam (Table 1). By the USDA standard, it will be referred to as Typic Ustroepts (Wuese, 2013).

Table 1: The soil characteristics of the study site

\begin{tabular}{lccccccccccccc}
\hline $\begin{array}{l}\text { Sand } \\
(\%)\end{array}$ & Silt & Clay & \multicolumn{2}{c}{ PH } & Org. C & \multicolumn{2}{c}{ Total N Avail. P Cmol/Kg } & & & \\
& $(\%)$ & $(\%)$ & $\mathrm{H}_{2} 0$ & $\mathrm{Kcl}$ & $(\%)$ & $(\%)$ & $(\mathrm{ppm})$ & $\mathrm{Mg}$ & $\mathrm{Ca}$ & $\mathrm{Na}$ & $\mathrm{K}$ & CEC \\
\hline 82.1 & 7.8 & 10.1 & 6.35 & 5.70 & 1.403 & 0.071 & 59.83 & 2.30 & 4.97 & 1.24 & 0.59 & 7.68
\end{tabular}

Source: Wuese, (2013).

The soil here has low levels of organic matter $(0.5-3 \%)$, an abundance of clay mineral (kaolinite) especially on the surface of soils. Based on geology of Makurdi (sandstone over shale), the soil is poorly drained which makes it vulnerable to runoff and concurrent soil loss. The soils are generally subject to flooding and deposition of sediments. The surface soil is very dark greyish brown or dark reddish in colour, coarse sand to very gravelly loamy sand about $40 \mathrm{~cm}$ thick (Wuese, 2013). The subsoil is mottled grey sandy loam to sandy clay loam that extends to the water table. In the topsoil, the reaction is slightly acid (pH 6.3), low exchangeable bases and Cation Exchange Capacity while the base saturation is very high.

The drainage system is generally ephemeral. Patches of marshes are found haphazardly around the University Campus.
Generally, the surface configuration of the Campus is a gentle undulating area. In the north core, where the research farm is, the elevation is $115 \mathrm{~m}$ above sea level, whereas, the University has an average elevation of about $97 \mathrm{~m}$. The place has a typical wet and dry season climate (Koppen's AW). The wet season sets in April and retreats in October with its peak occurring in June and September while the dry season is from November to March. Rainfall ranges between $1200 \mathrm{~mm}-2000 \mathrm{~mm}$ (Tyubee, 2005). The dry season which has low relative humidity starts from November and terminates in March. The most significant characteristics of this climate are the seasonality of rainfall which is intense, convectional and of short duration. This type of rainfall constitutes an active agent of detachment and transportation of soils capable of causing appreciable soil loss (Iorkua, 2013). The 
temperature shows highest value in the months of March and April $\left(37^{\circ} \mathrm{c}\right)$ and the lowest value in the months of November through January $\left(19^{\circ} \mathrm{c}\right)$ which agrees with Tyubee, (2005).

The drainage system is generally ephemeral. Patches of marshes are found haphazardly around the University Campus. Generally, the surface configuration of the Campus is a gentle undulating area. In the north core, where the research farm is, the elevation is $115 \mathrm{~m}$ above sea level, whereas, the University has an average elevation of about $97 \mathrm{~m}$. The place has a typical wet and dry season climate (Koppen's AW). The wet season sets in April and retreats in October with its peak occurring in June and September while the dry season is from November to March. Rainfall ranges between $1200 \mathrm{~mm}-2000 \mathrm{~mm}$ (Tyubee, 2005). The dry season which has low relative humidity starts from November and terminates in March. The most significant characteristics of this climate are the seasonality of rainfall which is intense, convectional and of short duration. This type of rainfall constitutes an active agent of detachment and transportation of soils capable of causing appreciable soil loss (Iorkua, 2013). The temperature shows highest value in the months of March and April $\left(37^{\circ} \mathrm{c}\right)$ and the lowest value in the months of November through January $\left(19^{\circ} \mathrm{c}\right)$ which agrees with Tyubee, (2005).

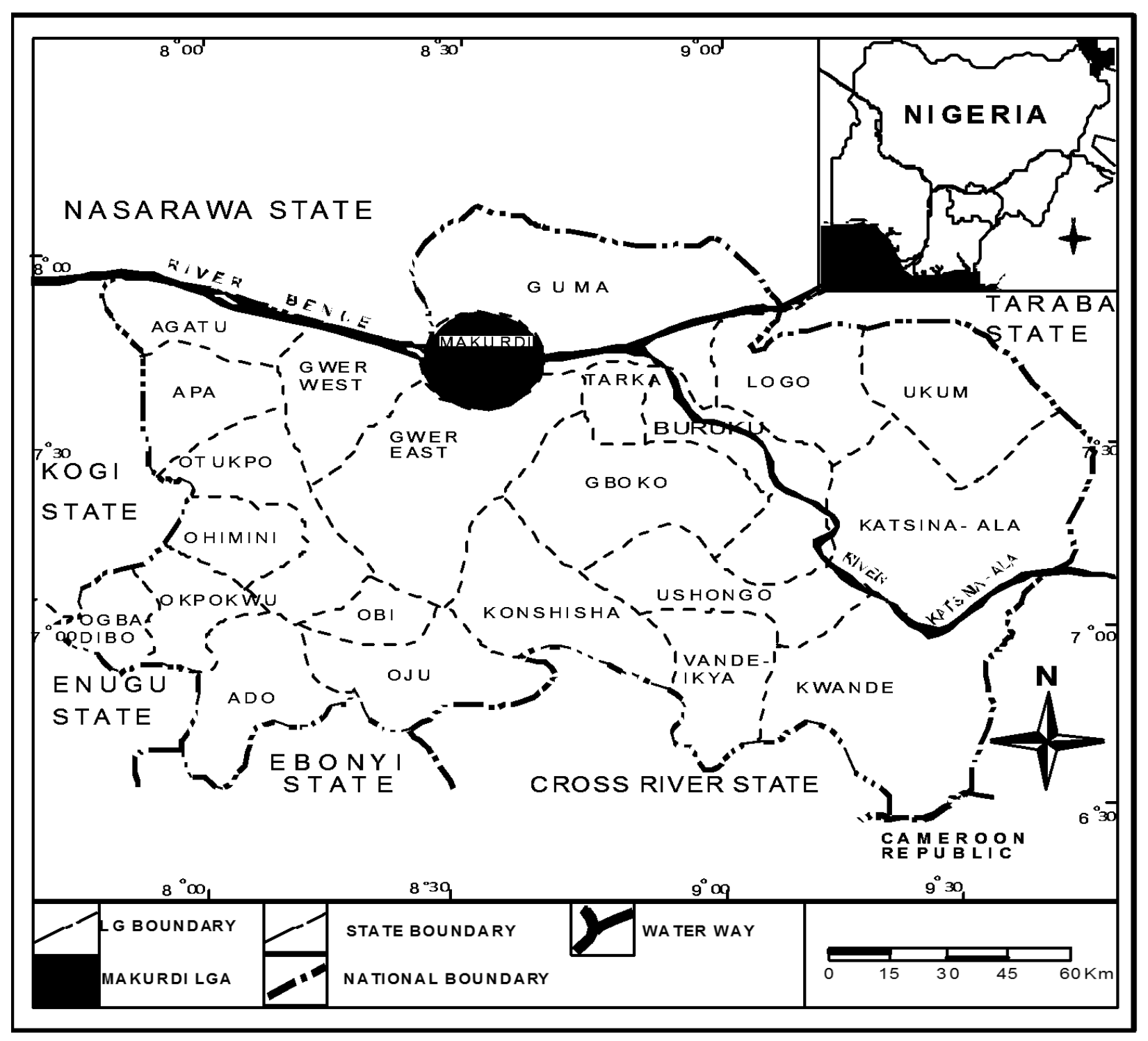

Figure 1: Map of Benue State showing Makurdi

Source: Adapted from Benue State Ministry for Lands and Survey (2017) 


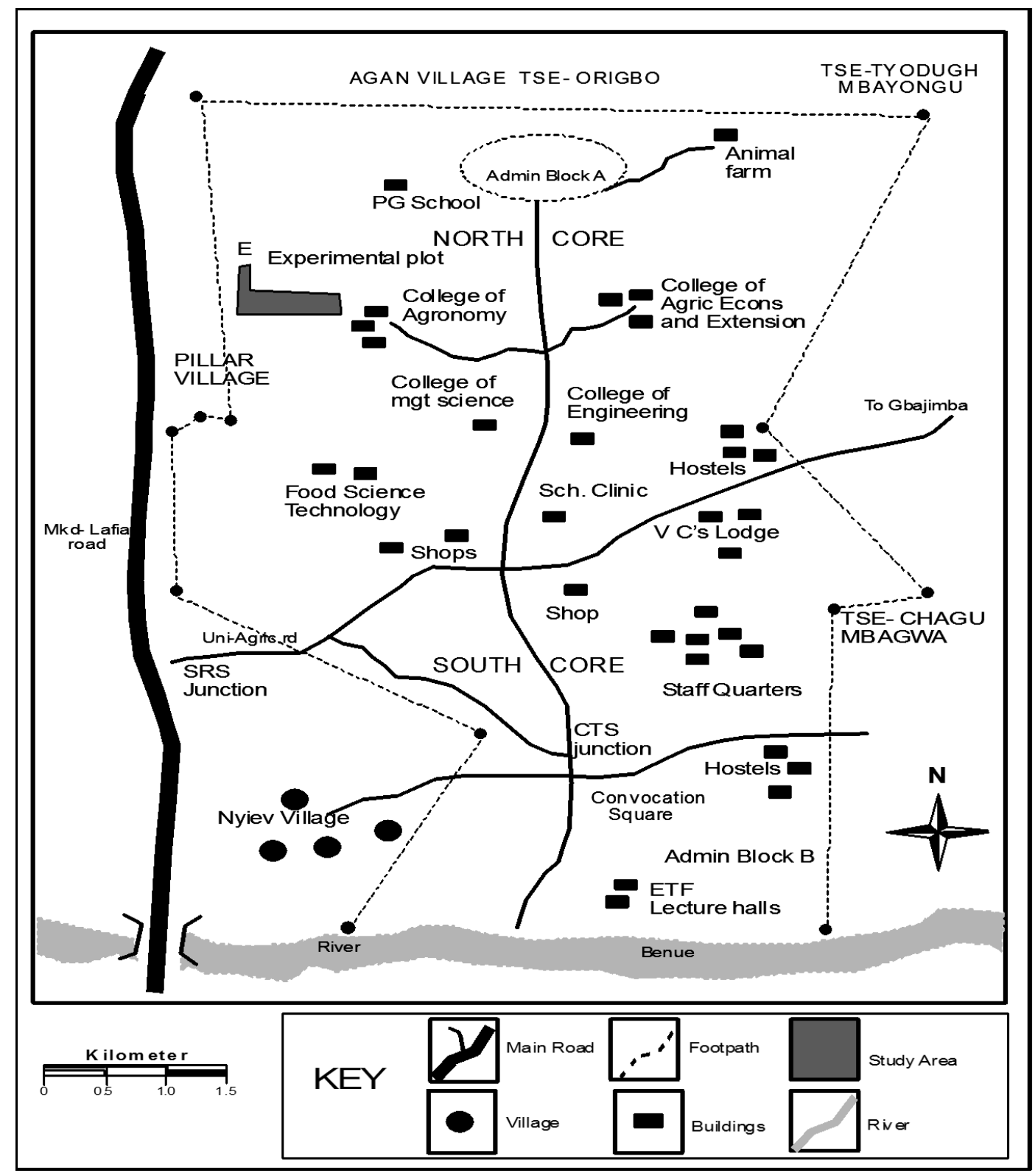

Figure 2: Map of University of Agriculture, Makurdi showing the study site Source: Adapted from Benue State Ministry of Lands and Survey (2017)

The vegetation of the north central Nigeria is the savannah grasslands zone. The study area is located within the guinea savannah biome of the grassland region. This biome has been described by Webster and Wilson, (1980) as a climax vegetation with broad leaf where deciduous trees are dominant and widely spaced with discontinuous canopy against continuous ground cover often mainly of grass but partly of wood and scattered species of trees. The dominant plant species of trees in the study area include locust bean tree (parkia biglobosa), Daniela olivera, shea butter tree (Butrospernumparaxdiumaccidentale), guava (psidiumguajava), pawpaw (caricapapya), palm trees (elaeisguinniensis) Teak trees, Neem tree and banana (musaspp). These dominant plant species grow mostly as single stands in the built-up areas where they provide shade and act as wind storm break. Most of the plant species except Daniela olivera, locust bean tree and shea butter tree others appear to have been planted by land users to replace the original trees removed by development. Some of the weeds that can be found in the study area are the carpet grass (axonopuscompressus), water leaf (talinum triangular), giant star grass, elephant grass, spear grasses with the height of 1-3m tall thick-barked trees of $10-15 \mathrm{~m}$ high. These species of plants and grasses surfer dry spell fire out break annually.

Makurdi town in general is an administrative sit and it is the centre point for all socio-economic activities in Benue state, like; transportation, trading, banking etc. Federal university of Agriculture as an educational institution has her primary activities, teaching and 
learning. The university environs are surrounded by the host communities with their main source of livelihood as farming. Within the university, farming activities are also found but, basically are demonstration farms for academic and research purposes. Other small scale businesses are also carried out on the campus like, computer shops (cyber café), provision stores and other food items are sold within the university community.

\section{Data Collection and Analysis}

The study generated soil loss and runoff data over nine (9) experimental runoff plots at the College of Agronomy's farm, University of Agriculture
Makurdi. The experimental plots of were carved $20 \mathrm{~m}$ long by $3 \mathrm{~m}$ wide with an outlet down slope of $1.5 \mathrm{~m}^{2}\left(20 \mathrm{~m} \times 3 \mathrm{~m}+1.5 \mathrm{~m}^{2}=61.5 \mathrm{~m}^{2}\right)$, and bordered with corrugated iron sheets. It sheets were inserted into the ground to a depth of $20 \mathrm{~cm}$, leaving $25 \mathrm{~cm}$ above the soil surface to prevent lateral flows from the plots to the adjacent area and vice versa(Figure 3 ). The experimental plots were treated with organic materials; grasses and planted with maize (Plate 1). Mulch materials (grass) was weighed in tons and plots calibrated as zero (0) tons as control (T1), (4) tons as (T2), (8) tons as T3. The 3 scenario were replicated into 9 plots to enhance quality of data (Figure 3 ).

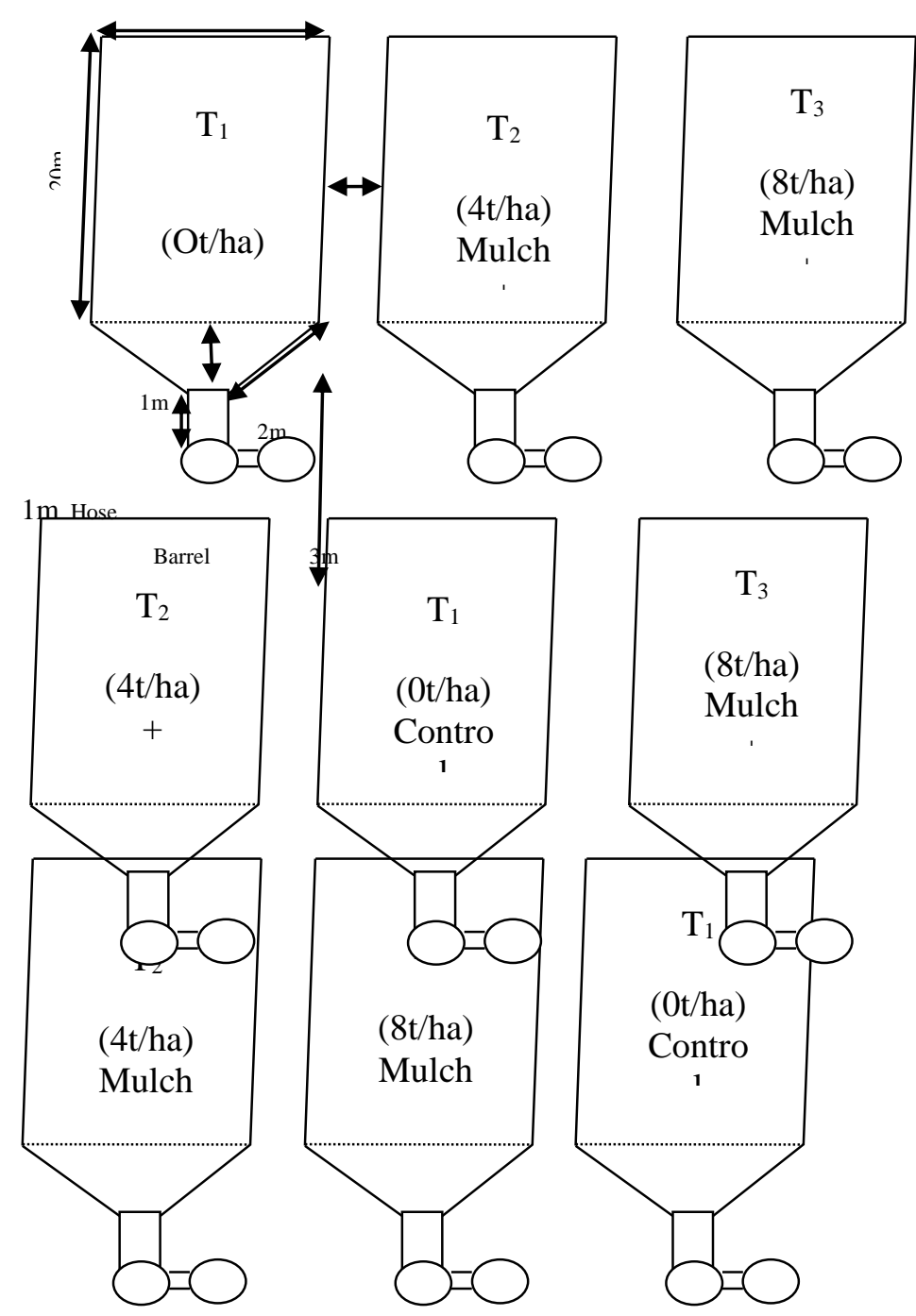

Figure 3: A Diagram of the Experimental Plots

Source: Author's Fieldwork, 2016. 


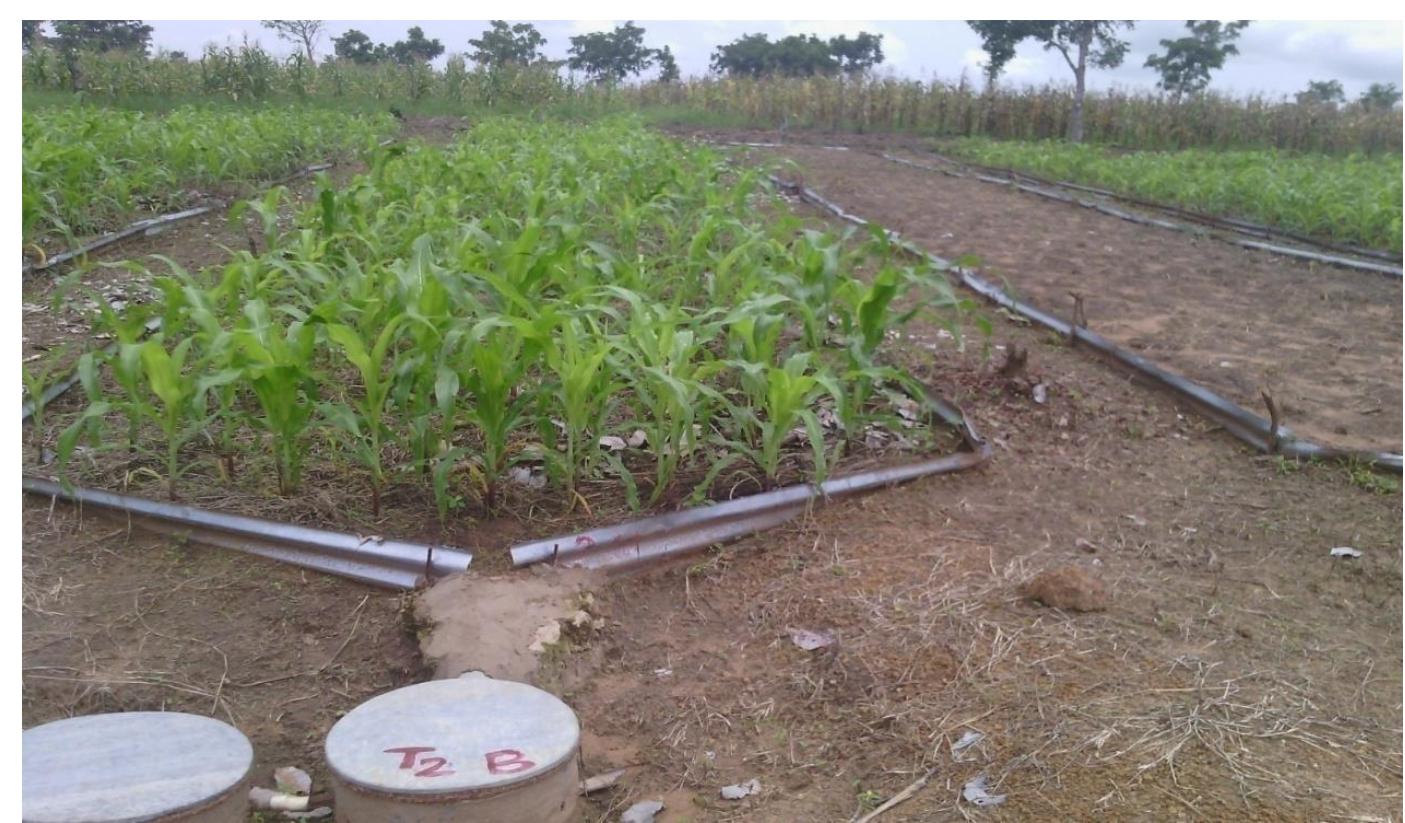

Plate 1: An example of the experimental plot planted with maize in the Study Area Source: Author's Fieldwork, 2016.

The study was conducted during raining season (August-September). Data collected in the field were analyzed using coefficient of variation as a main index to select the best linear and nonlinear relationship (Udofia 2011), between rainfall amount and studied variables i.e runoff rate or volume and soil loss amount as:

$$
C . V=\frac{\sigma}{\times} \times 100
$$

where; $\boldsymbol{C} . \boldsymbol{V}=$ co-efficient of variation, $\sigma=$ standard deviation, $x=$ mean of the distribution.

Also, correlation statistic technique and multiple regression statistic technique was applied to check the relationship between independent variables of rainfall amount and event, and, mulching on dependents variables of runoff and soil loss, between treated surfaces and the controlled plots.

\section{$Y_{.}=a+b_{1} \times 1+b_{2} \times 2+b_{3} \times 3 \ldots . . . b_{n} \times \times_{n}+e \quad$ (ii)}

Where;Y. = estimated value of the dependent variable

$$
\mathrm{a}=\mathrm{Y} \text { intercept }
$$

$\mathrm{b} 1, \mathrm{~b} 2, \mathrm{~b} 3, \ldots . . \mathrm{bn}=$ the regression plane of the three independent variables $\times 1 \times 2 \times 3, \ldots \times \mathrm{n}=$ the independent.
Again two way ANOVA were employed to ascertain the variation between variables. These techniques were summarized with SPSS 20 package. The amount of soil loss was measured using a decantation procedure; the soil was ovendried at $105^{\circ} \mathrm{C}$ for $24 \mathrm{hrs}$ and weighed by means of high-precision scales

\section{Results and Discussion}

Rainfall, Runoff and Soil Loss Characteristics of the Study Area

The results from the field reveals varied amount of water discharged from different plots. The discrepancy within and amongst the treated surfaces is presented in two phases as mean performance and total performance. In the result, individual rainstorms produced varied 'means' on amount of runoff and soil loss from individual plots. On runoff, controlled plots produced higher amount all through. The volume of water discharge on TI high compared to T2 and T3. There is a consistent decrease in runoff volume as rates of surface cover increases in the research. For example, the rainfall on $2^{\text {nd }}$ August 2016 event had $3.1 \mathrm{~mm}, 0.2 \mathrm{~mm}$ and $0 \mathrm{~mm}$ on $\mathrm{T} 1$, T2 and $\mathrm{T} 3$ respectively (Table 2 ) 
Table 2: Rainfall Runoff (mm) and Soil Loss (kg) in the Farm Plots

\begin{tabular}{|c|c|c|c|c|c|c|c|c|c|c|c|}
\hline Event & & Plot & A & B & $\mathrm{C}$ & $\mathrm{RF}$ & & $\% \mathrm{RF}$ & SL & $\% \mathrm{SL}$ & MR \\
\hline \multirow{3}{*}{\multicolumn{2}{|c|}{$2 / 8 / 16$}} & $\mathrm{~T} 1$ & 1.01 & 1.06 & 1.03 & 3.1 & & 97.3 & 3.3 & 100 & 2.4 \\
\hline & & $\mathrm{T} 2$ & 0 & 0.01 & 0.01 & 0.2 & & 0.76 & 0 & 0 & \\
\hline & & $\mathrm{T} 3$ & 0 & 0 & 0 & 0 & & 0 & 0 & 0 & \\
\hline \multirow{3}{*}{\multicolumn{2}{|c|}{$3 / 8 / 16$}} & $\mathrm{~T} 1$ & 9.3 & 9.3 & 8.9 & 27.5 & & 99.5 & 8.8 & 100 & 31.0 \\
\hline & & $\mathrm{T} 2$ & 0 & 0.4 & 0.4 & 0.8 & & 2.6 & 0 & 0 & \\
\hline & & $\mathrm{T} 3$ & 0.02 & 0 & 0.01 & 0.03 & & 0.09 & 0 & 0 & \\
\hline \multirow[t]{3}{*}{$7 / 8 / 16$} & & $\mathrm{~T} 1$ & 1.02 & 1.08 & 1.06 & 3.2 & & 89.9 & 14.4 & 100 & 2.6 \\
\hline & $\mathrm{T} 2$ & 0.05 & 0.07 & 0.08 & 0.2 & & 5.4 & 0 & 0 & & \\
\hline & & $\mathrm{T} 3$ & 0.04 & 0.06 & 0.05 & 0.2 & & 4.3 & 0 & 0 & \\
\hline \multirow[t]{3}{*}{$15 / 8 / 16$} & & $\mathrm{~T} 1$ & 5.9 & 5.8 & 5.06 & 16.8 & & 96 & 45.3 & 100 & 15.8 \\
\hline & & $\mathrm{T} 2$ & 0.04 & 0.3 & 0.1 & 0.5 & & 2.9 & 0.8 & 0 & \\
\hline & & $\mathrm{T} 3$ & 0.03 & 0.04 & 0.08 & 0.2 & & 0.8 & 0 & 0 & \\
\hline \multirow[t]{3}{*}{$19 / 8 / 16$} & & $\mathrm{~T} 1$ & 7.6 & 7.6 & 7.8 & 23 & & 96.7 & 15.8 & 100 & 16.0 \\
\hline & & $\mathrm{T} 2$ & 0.03 & 0.2 & 0.3 & 0.5 & & 2.4 & 0 & 0 & \\
\hline & & $\mathrm{T} 3$ & 0.08 & 0.04 & 0.05 & 0.2 & & 0.7 & 0 & 0 & \\
\hline \multirow[t]{3}{*}{$24 / 8 / 16$} & & $\mathrm{~T} 1$ & 1.5 & 1.8 & 1.6 & 4.9 & & 99.3 & 17.8 & 100 & 5.1 \\
\hline & & $\mathrm{T} 2$ & 0 & 0.02 & 0 & 0.02 & & 0.5 & 0 & 0 & \\
\hline & $\mathrm{T} 3$ & 0 & 0 & 0 & 0 & & 0 & 0 & 0 & & \\
\hline \multirow[t]{3}{*}{$26 / 8 / 16$} & & $\mathrm{~T} 1$ & 0.5 & 0.4 & 0.7 & 1.6 & & 99.8 & 4.1 & 100 & 2.0 \\
\hline & & $\mathrm{T} 2$ & 0 & 0 & 0 & 0 & & 0 & 0 & 0 & \\
\hline & & $\mathrm{T} 3$ & 0 & 0 & 0 & 0 & & 0 & 0 & 0 & \\
\hline \multirow{3}{*}{\multicolumn{2}{|c|}{$4 / 9 / 16$}} & $\mathrm{~T} 1$ & 5.6 & 5.5 & 5.5 & 16.6 & & 95.5 & 40.6 & 100 & 12.4 \\
\hline & & $\mathrm{T} 2$ & 0.03 & 0.2 & 0.3 & 0.5 & & 3.4 & 0 & 0 & \\
\hline & & $\mathrm{T} 3$ & 0.02 & 0.07 & 0.08 & 0.2 & & 1.0 & 0 & 0 & \\
\hline \multirow{3}{*}{\multicolumn{2}{|c|}{$5 / 9 / 16$}} & $\mathrm{~T} 1$ & 7.1 & 7.6 & 7.5 & 22.2 & & 94.9 & 25.5 & 100 & 15.8 \\
\hline & & $\mathrm{T} 2$ & 0.2 & 0.6 & 0.1 & 0.9 & & 4.3 & 0 & 0 & \\
\hline & & $\mathrm{T} 3$ & 0.06 & 0.04 & 0.03 & 0.1 & & 0.6 & 0 & 0 & \\
\hline \multirow[t]{3}{*}{$12 / 9 / 16$} & & $\mathrm{~T} 1$ & 8.2 & 9.8 & 7.8 & 25.8 & & 94.1 & 18.4 & 100 & 56.4 \\
\hline & & $\mathrm{T} 2$ & 0.2 & 0.4 & 0.8 & 1.4 & & 5.1 & 0 & 0 & \\
\hline & & $\mathrm{T} 3$ & 0.03 & 0.03 & 0.08 & 0.1 & & 0.5 & 0 & 0 & \\
\hline
\end{tabular}

MR= Mean Rainfall, RF= Runoff, SL= Soil Loss. Source: Field Work, 2016

Similarly, $12^{\text {th }}$ September 2016 rainfall had same trend of decrease of mean discharge on their various plots. On the other hand, soil loss like runoff, also produced high volume of soil loss on $\mathrm{T} 1$ plot unlike the the treated $\mathrm{t} 2$ and $\mathrm{T} 3$ surfaces. The decrease in volume of soil loss with an increase in rate of mulching experienced in this study conform to the work of Lal (1997) and Smith (1997). There was a total soil loss conservation noticed at 8 tons mulch rate, where no soil loss was recorded throughout study period. The T1 produced above 'mean' both runoff and soil loss on each rainfall, while all the treated surfaces produced below the average of both runoff and soil loss. The total performance also followed the trend of increased discharge with decreased surface cover. The amount of water discharged on a whole was more, on controlled plots than the treated plots of 4 tons mulch and 8 tons mulch.

\section{Runoff and Soil Loss Pattern of the Experimental Farm Plots}

The focus of this research is to examine the influence of mulching on runoff amount on varied treatment of 4tons and 8tons. Runoff is always the water that has remained on the surface of the soil and moves as overland flow, or it is the hydrograph resulting to the movement of rainfall excess over the watershed surface to its outlet. The result from table 2 revealed varied discharges from different treated surfaces (plots). The discrepancies exhibited on these plots shows that, within a small catchment, different levels of discharges exist. From the result, almost similar trend of values are gotten within plots. Generally, differences among plots are glaring from the result. On controlled plots, similar pattern of result occurred on the $2^{\text {nd }} 3^{\text {rd }} 7^{\text {th }} \& 19^{\text {th }}$ August 2016 rainfall events, and $4^{\text {th }} \& 5^{\text {th }}$ September 2016. On the other hand, $15^{\text {th }} 24^{\text {th }} \& 26^{\text {th }}$ August 2016 and $12^{\text {th }}$ September 2016 do not agree with the trend (table 2). Although, the differences might be from other factors (rainfall parameters of intensity, duration and soil moisture regime) that are not involved in this study based on absence of automated meteorological rain gauge or unequal spread mulch treatment during preparation of experimental plots and fairly ununiform slope on the study site. 
Examining the result from mulch surfaces of 4tons records, the percentages on $15^{\text {th }}$ August $(0.22 \%, 2.04 \%, \& 0.73 \%), 19^{\text {th }}$ August $(0.12 \%$, $0.84 \% \& 1.47 \%), 24^{\text {th }}$ August $(0 \%, 0.56 \%, \&$ $0 . \%), 4^{\text {th }}$ September $(0.17 \%, 1.15 \% \& 2.1 \%), 5^{\text {th }}$ September $(0.89 \%, 2.86 \%, \& 0.57 \%)$ and $12^{\text {th }}$ September 2016, $(0.72 \%, 1.46 \%$ \& $2.9 \%)$ do not record a particular pattern unlike other rainfall event with similar records, for example, on the $2^{\text {nd }}$ August (0\%, 0.38\% \& 0.38\%), $3^{\text {rd }}$ August (0\%, $1.3 \% \& 1.3 \%) 7^{\text {th }}$ August $(1.4 \%, 1.8 \% \& 2.2 \%)$, and $26^{\text {th }}$ August 2016, (0\% each) in the study. The plots of 8tons mulch treated surfaces, virtually recorded similar trend.

Generally, the result revealed that some rain events produced runoff more than others, and individual plots also produced different reaction. For examples, $3^{\text {rd }}, 24^{\text {th }}$, \& $26^{\text {th }}$ August 2016,
(99.5\%, $99.3 \%$ \& $99.8 \%$ respectively) on controlled plots recorded highest amount of runoff. Mulched plots of 4tons recorded highest runoff on $7^{\text {th }}$ August, $5^{\text {th }}$ and $12^{\text {th }}$ September 2016, $(5.4,4.32 \& 5.08)$. On mulched surfaces of 8tons plots, there was a general low volume of runoff recorded, only $7^{\text {th }}$ August (4.3) and $4^{\text {th }}$ September (1.02) produced more than $1 \%$ across the study period. Table 2 shows the average discharge of water on control and mulched plots. The table shows that $48.20 \mathrm{~mm} w a \mathrm{~s}$ recorded on the controlled plot whereas $1.61 \mathrm{~mm}$ and $0.31 \mathrm{~mm}$ was recorded on the treated plots (4tons \& 8tons) respectively. This revealed that, $96.14 \%$ of discharge occurred on controlled plot with only $4.1 \%$ (3.22\% on 4 tons and $0.63 \%$ on 8 tons) being recorded on the mulched surfaces.

Table 3: Total Runoff from the Experimental Plots with Percentages

\begin{tabular}{lllllllllll} 
Plots & A & B & C & Total Rff $(\mathrm{mm})$ & A $\%$ & B\% & C\% & MeanRff & T/\%Roff \\
& & & & & & & & & \\
\hline Otons & 47.73 & 49.94 & 46.95 & 144.62 & 31.73 & 33.2 & 31.21 & 48.20 & 96.14 \\
4tons & 0.55 & 2.2 & 2.09 & 4.84 & 0.37 & 1.46 & 1.39 & 1.61 & 3.22 \\
8tons & 0.28 & 0.28 & 0.38 & 0.94 & 0.19 & 0.19 & 0.25 & 0.310 .63 \\
Total & $\mathbf{4 8 . 5 6}$ & $\mathbf{5 2 . 4 2}$ & $\mathbf{4 9 . 4 2}$ & $\mathbf{1 5 0 . 4}$ & & & & & $\mathbf{1 0 0}$
\end{tabular}

Source: Field Work, 2016.

This percentage $(96.14 \%, 3.22 \% \&$ $0.63 \%$ ) implied that an increase in mulch rate drastically reduces volume of water discharge (runoff). From this result, it is evidently clear that, there are lots of water and nutrients lost on agrarian lands where there is no protective cover. Figure 1 graphically represents the information per individual plot i.e within $\mathrm{ABC}$, and figure 2 represent on a gross (total) level among plots i.e Otons, 4tons \& 8tons.

This study aimed at evaluating impact of soil surface cover on soil loss to determine whether or not, there is a significant effect on soil loss. Using Soil Loss Estimate Model for Southern Africa (SLEMSA) as described in section 2.3.1, the amount of soil loss was examined. The effect of cover (mulch) on soil loss was glaring as shown by tables 1 and 2 in this study. The result of the analysis as displayed from the tables 1 and 2, show that, soil loss from bare surface at each plot was more than the quantity from the two mulch treatment put together. Table
2 revealed gross soil loss volume on control plots were; 48.8, 59.2 and $84.7 \mathrm{~kg} / 184.5 \mathrm{~m}^{2} /{ }^{1 / 4} \mathrm{yr}$ at $\mathrm{ABC}$ replicates respectively. The soil loss volume from the mulched surfaces (4tons) were 0.2, 1.6 and $1.3 \mathrm{~kg} / 184.5 \mathrm{~m}^{2} / 1 / 4 \mathrm{yr}$ at replicates respectively, whereas, the least soil loss from mulch surface (8tons) recorded $0 \mathrm{~kg} / 184.5 \mathrm{~m}^{2} /{ }^{1 / 4} \mathrm{yr}$ each plot.

Analysis from Table 3 shows percentage of soil loss volume decreasing with increasing surface cover in this study. The results from the bare surface (without mulch) were 99.6, 97.4 \& 98.5 replicates $(\mathrm{ABC})$. Conversely, a total of $193.7 \mathrm{~kg} / 184.5 \mathrm{~m}^{2} /{ }^{1 / 4} \mathrm{yr}$ or, $98.5 \%$ soil losses were recorded. The result from the mulched surface (4tons \& 8tons) combined were far less than the bare surface (control). At 4tons replicated plots, records were $3.1 \mathrm{~kg} / 184.5 \mathrm{~m}^{2}{ }^{1 / 4} \mathrm{yr}$ (or $0.4,2.6 \&$ 1.5 respectively), while at 8 tons replicated plots were $0 \mathrm{~kg} / 184.5 \mathrm{~m}^{2} /{ }^{1 / 4} \mathrm{yr}(0,0 \& 0$ each).

In this study, the discrepancies of soil loss volume maybe attributed to; the rate of mulch 
materials filtering soil particles that might be in motion allowing only the fluid to pass through, the root of maize planted and leaves which help stabilized soil structure (i.e the spacing of a stand $25 \mathrm{~cm}$ on row and $75 \mathrm{~cm}$ on column), the factor of soil moisture regime, soil surface sealing, or, crust and compaction observed in the course of this study. These factors observed combined to affect soil infiltration capacity based on; rainfall parameters of event, amount, duration and intensity, although, intensity and duration was not considered in this study.

Table 4: Soil Loss on Experimental Plots

\begin{tabular}{lcccllllll}
\hline Plots & A & B & C & $\begin{array}{l}\text { Total } \\
\text { S.L }(\mathrm{kg})\end{array}$ & A\% & B\% & C\% & $\begin{array}{l}\text { Mean } \\
\text { SL }\end{array}$ & $\begin{array}{l}\text { \%soil } \\
\text { loss }\end{array}$ \\
\hline 0tons & 48.8 & 59.2 & 84.7 & 193.7 & 35 & 30.6 & 43.7 & 2.15 & 98.4 \\
4tons & 0.2 & 1.6 & 1.3 & 3.1 & 6.4 & 51.6 & 41.9 & 0.03 & 1.6 \\
8tons & 0 & 0 & 0 & 0 & 0 & 0 & 0 & 0 & 0 \\
Total & 50 & 60.8 & 86 & 196.8 & & & & & 100 \\
\%0tons & 99.6 & 97.4 & 98.5 & & & & & & 98.5 \\
\%4tons & 0.4 & 2.5 & 1.5 & & & & & & 1.5 \\
\%8ton & 0 & 0 & 0 & & & & & & 0 \\
\hline
\end{tabular}

Source: Field Work, 2016

\section{The Effect of Rainfall Amount on Surface Runoff}

This section aimed at evaluating the effect of the amount of rainfall on volume of runoff. The amount of rainfall per rain event was checked on one hand and total volume of runoff on the other hand. In the course of this study, a total rainfall amount of $159.5 \mathrm{~mm}$ was recorded, whereas, gross runoff volume of $150.4 \mathrm{mmwas}$ recorded. The amount of rainfall $(159.5 \mathrm{~mm})$ from 10 rainstorms produced varied volumes of runoff from the plots, (bare surface (un-mulched) and mulched areas). The volume of runoff produced on bare surface (control) doubled the plots with mulched material (4tons \& 8tons) put together. The volume of runoff recorded on control was $144.62 \mathrm{~mm}$ which was 28 times more than mulched plots of 4tons $(4.84 \mathrm{~mm})$ while on 8 tons $(0.94 \mathrm{~mm})$ mulched plots, it is over hundred and thirty-four (134) times.

Only six rainstorms that produced runoff on all the plots (0tons, 4tons \& 8tons) $7^{\text {th }}, 15^{\text {th }}$, and $19^{\text {th }}$ August, and $4^{\text {th }}, 5^{\text {th }}$, and $12^{\text {th }}$ September respectively, while some of the rainfall events produced runoff amount more than others, for example, $2.6 \mathrm{~mm}$ and $12.4 \mathrm{~mm}$ recorded highest amount $4.3 \% \& 1.02 \%$ on 8 tons plots $\left(7^{\text {th }}\right.$ August $\& 4^{\text {th }}$ September) respectively. Similarly, 4tons mulched plots had highest amount of runoff recorded on $7^{\text {th }}$ August $(2.6 \mathrm{~mm}), 4^{\text {th }}(12.4 \mathrm{~mm}), 5^{\text {th }}$ $(15.8 \mathrm{~mm})$ and $12^{\text {th }}$ September $(56.4 \mathrm{~mm}) 5.4 \%$, $3.42 \%, 4.32 \%$ and $5.08 \%$ respectively. On the other hand, control plots (un-mulched) had $99.5 \%, 99.3 \%$ and $99.8 \%$ highest runoff volume on $3^{\text {rd }}, 24^{\text {th }}$ and $26^{\text {th }}$ August respectively. Worthy of note, further comparison of same amount of rainfall recorded on the $15^{\text {th }}$ August and $5^{\text {th }}$ September $(15.8 \mathrm{~mm})$ produced different volume of water discharge $12.5 \%$ and $15 \%$ respectively. This discrepancy may arise from the timing of rain event between $7^{\text {th }}$ to $15^{\text {th }}$ August (which is almost one week) that will encourage infiltration capacity of the soil and limit runoff. On the other hand, the interval between $4^{\text {th }}$ and $5^{\text {th }}$ September clearly shows that, soil moisture regime determine the level of rainfall infiltration on comparable cover surfaces and the level at which water discharge on these surfaces. Again, the records revealed that, there is no correlation between rainfall amount and amount of water discharge. For example, rainstorm on $12^{\text {th }} / 9$ $(56.4 \mathrm{~mm})$ had second highest $19.7 \%$ after $3^{\text {rd }}$ August (31mm) 20.2\%.

Generally, looking at the total discharge of water, the volume decreases with the increase in soil surface cover. This pattern of result conformed to the studies of Lal (1997), Ghalome etal (2013) and Balvinder et al (1988). They both argued and agreed in their studies that, organic mulches conserve water on farm fields (plots) more effectively as to bare surfaces. In a similar vein, smith et' al (1995) concludes that, an increase in mulch rate $1.5 \mathrm{~cm}$ or 0.6 inch of straw mulch reduced water runoff by $43 \%$. 
In this study, virtually all rainfall events produced runoff volume more than $96.14 \%$ on control plots. Conversely, only less than $5 \%$ of rainfall contributes to soil moisture through infiltration. On the other hand, only $4 \%$ discharge volume was recorded on 4tons $(3.22 \%)$ whereas, less than $1 \%(0.63 \%)$ discharge was on 8tons plots respectively (see Table 3 ). In the similar vein, $96.6 \%$ of rain water was conserved in the soil with the amount $159.5 \mathrm{~mm}$ of rainfall recorded on mulched surface of 4tons while 99.3\% rain water was conserved on 8tons.

From Table 3, the average discharge of water on control and mulch plots. The table shows that $48.20 \mathrm{~mm}$ was recorded on control plots whereas $1.61 \mathrm{~mm}$ and $0.31 \mathrm{~mm}$ were on the treated plots 4tons and 8tons respectively. Figure 4 explains per rainstorm percentage of runoff amount and amount of rainfall on the mulched surfaces.

Figure 4: General pattern on Rainfall-Runoff across the study

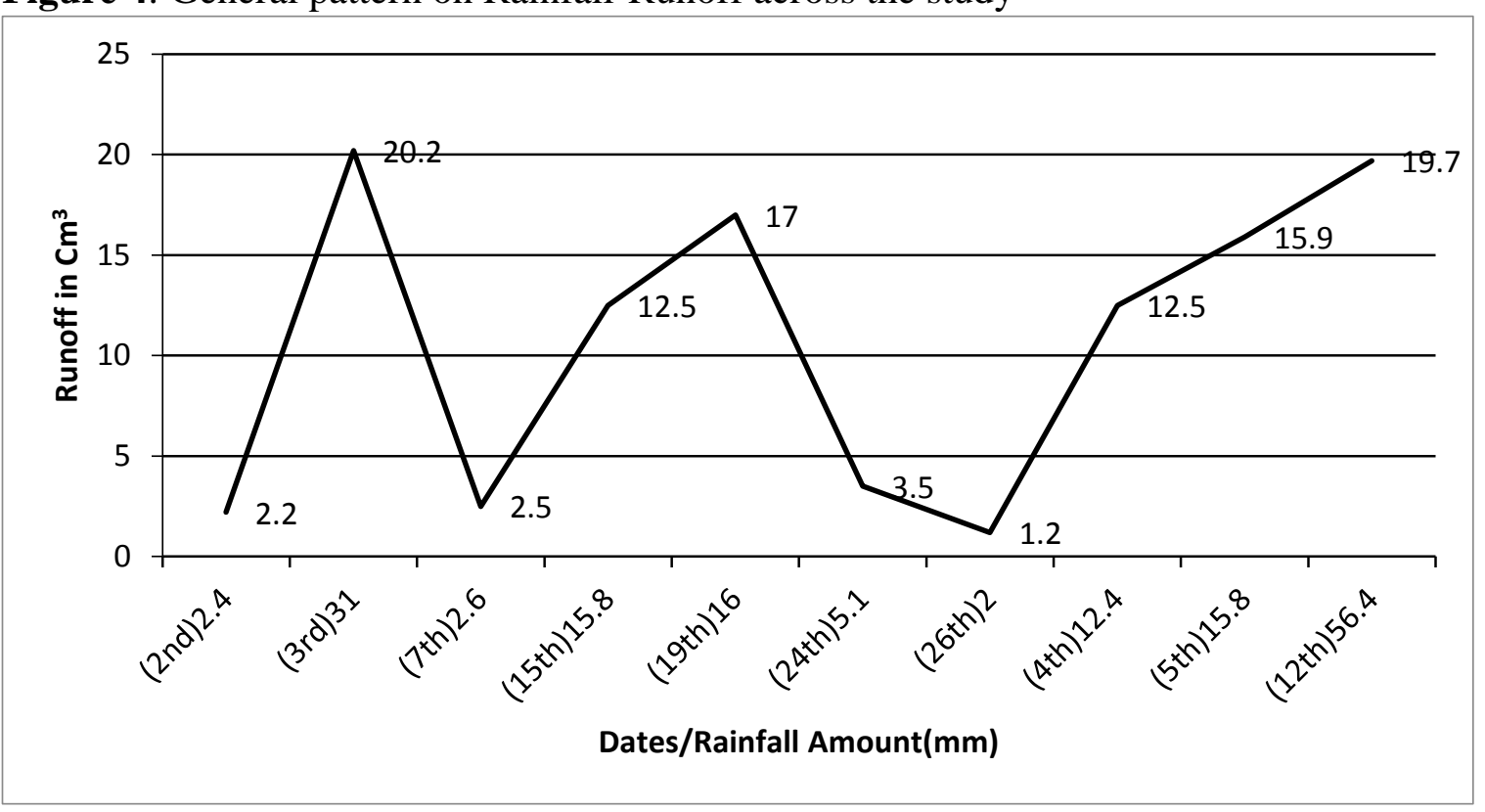

\section{The Effect of Rainfall Amount on Volume of Soil Loss}

This study aimed at examining rainfall amount and event (i.e timing) on its' influence on volume of soil loss recorded in the course of this study. As discussed earlier, total amount of rainfall was $159.5 \mathrm{~mm}$ and total soil loss $196.8 \mathrm{~kg} / 184.5 \mathrm{~m}^{2} /{ }^{1 / 4} \mathrm{yr}$ were recorded. The records on $2^{\text {nd }}, 7^{\text {th }}$ and $19^{\text {th }}$ August presented a similar results on volume of soil loss in all the replicated plots, whereas, the remaining rainfall produced only two similar values instead of three replicates. These varied figures may be from the uneven slope nature of farm land or, from the preparation of study site. The result from table 3 revealed that, highest rainfall amount $56.4 \mathrm{~mm}$ on $12^{\text {th }}$ September recorded $18.4 \mathrm{~kg} / 184.5 \mathrm{~m}^{2} /{ }^{1 / 4} \mathrm{yr}$ $(9.3 \%)$ soil losses. On the other hand, $15^{\text {th }} / 8$ rainfall event $(15.8 \mathrm{~mm})$ recorded highest volume of soil loss $47.9 \mathrm{~kg} / 184.5 \mathrm{~m}^{2} /{ }^{1 / 4} \mathrm{yr}(24.3 \%)$. This explained that, there is no perfect relationship established between extreme rainfall amount and extreme soil loss. That is, soil loss is not a function of rainfall amount alone. It is also controlled by some other factors of rainfall, duration, intensity and kinetic energy of raindrop i.e erosivity and other soil characteristics of compaction, crust and sealing and soil moisture regime that jointly affect the volume and rate of soil detachment and transport. This study conformed with the conclusions drawn by Bryan (1969), Daura, (1995) Eze, (1996) and Iorkua, (2013), that gross splash i.e detached soil, over all mulch treatments were lowest in July (within the month range of this study). According to their explanation, July usually marks the middle of the rainy season in most parts of Nigeria, including the present study area, and is a period when the soil gets saturated and aggregated by the process of slaking and surface crusting, processes that encourage runoff and reduce splash. This aided in explaining low volume and rate of soil loss experienced in the course of this study. In this research, the emphasis was on the differences in surface treatment ranging from July to September 
unlike Iorkua (2013) and the mentioned researchers for a whole season.

Gross total soil loss was recorded highest on control plots $193.7 \mathrm{~kg} / 184.5 \mathrm{~m}^{2} /{ }^{1 / 4} \mathrm{yr}$. This was more than that recorded on mulched treatments $3.10 \mathrm{~kg} / 184.5 \mathrm{~m}^{2} /{ }^{1 / 4} \mathrm{yr}$ and $0 \mathrm{~kg} / 184.5 \mathrm{~m}^{2} /{ }^{1 / 4} \mathrm{yr}$ combined on 4tons and 8tons respectively. Records from this study were generally low, coinciding with the records of Iorkua (2013) and the conclusions cited in his review. This is further explained in fig 6, rainfall amount and soil loss volume trend across study period.

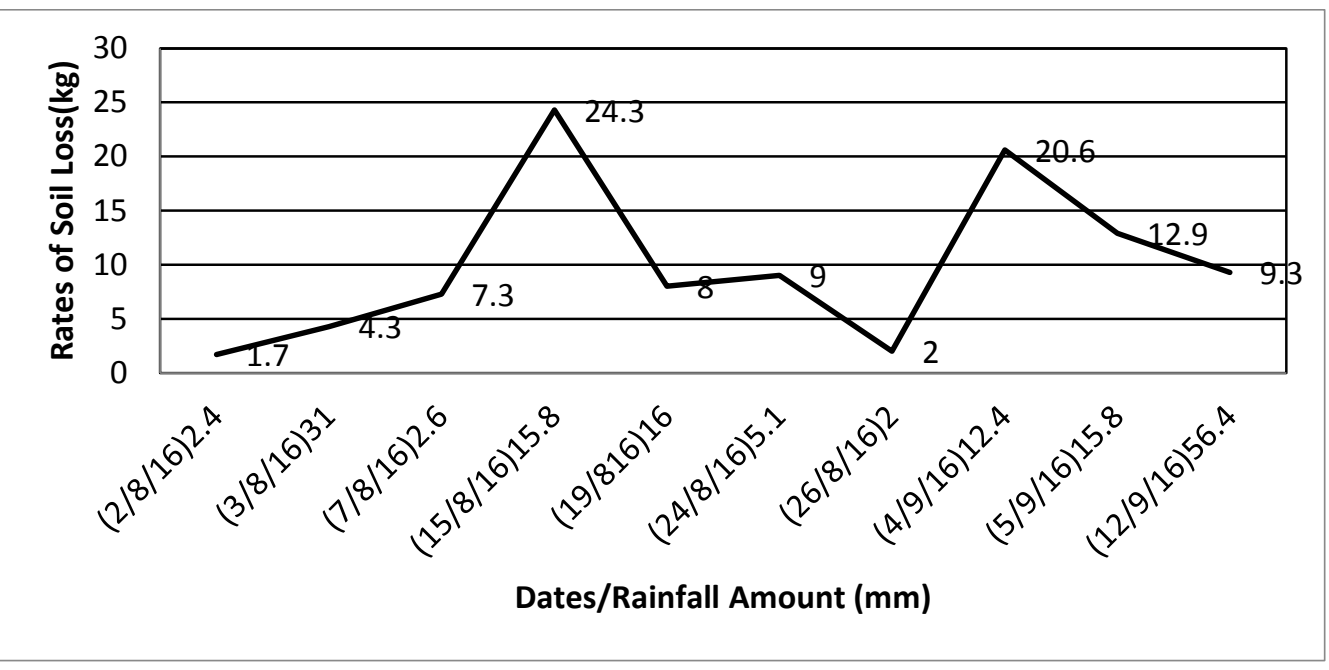

Figure 5 Rainfall-Soil Loss pattern (trend) across study period.

Generally, figure 6 explains that, the amount of rainfall has no significance in producing soil loss amount from mulched treatments of 4tons and 8tons respectively. Similarly, this study revealed in fig 7 that, $98.4 \%$ sediment yield on bare surface i.e 0tons, while mulched surfaces of 4tons and 8tons had $1.6 \% \&$ $0 \%$ respectively. Conversely, only $1.6 \%$ can be guaranteed against soil loss on bare surfaces. By implication, surface management is crucial, especially early season cultivation if not properly covered, the $98.4 \%$ recorded on bare surfaces is; not soil formation friendly, soil water deficit, a catalyst for land degradation by fluvial erosion, and sediment load that pollute surface water, and encourage deposition shallowing channel depth. On the other hand, mulched treatment plots had $1.6 \%$ \& $0 \%$ soil loss on 4tons and 8tons explains that, about $98.4 \%$ and $100 \%$ conservation of soil can be guaranteed in this research.

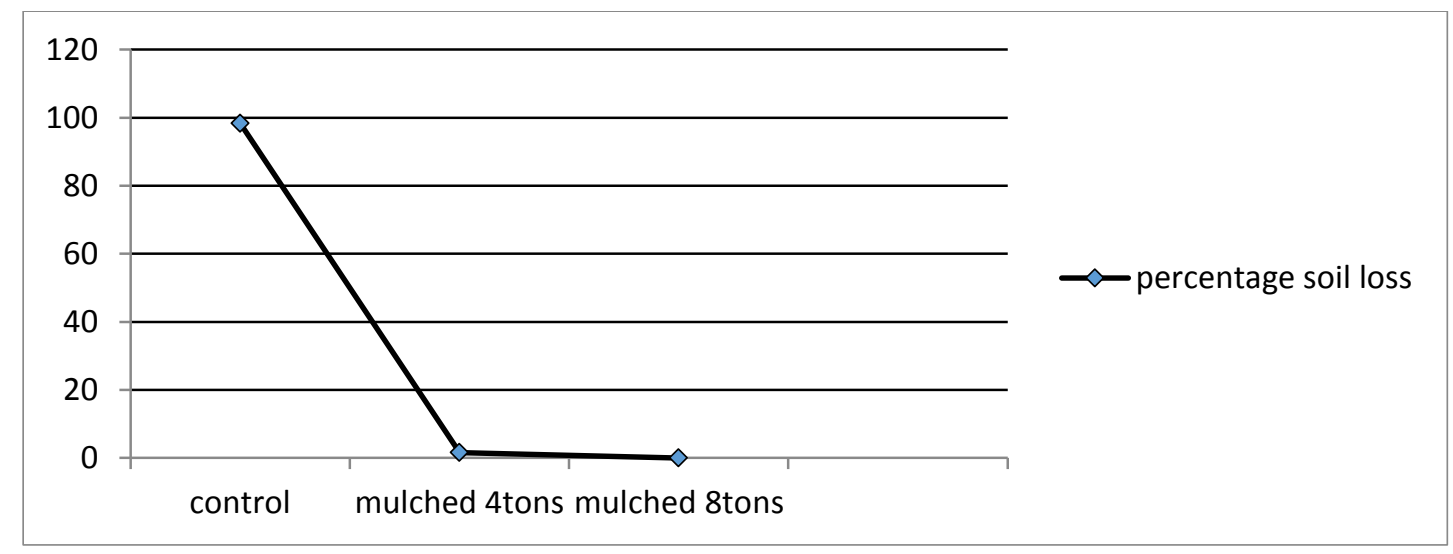

Figure 6: Percentage performance of soil loss amount across plots in the study. 
The Relationship between Rainfall, Runoff and Soil Loss on Mulched Plots

In the previous sections, explanations were inclined more on effect of rainfall parameters and mulching on the behavior of runoff and soil loss. This section focused attention on the strength of the relationship between variables studied i.e measuring the dependence of components of runoff and soil loss on the independent variables of mulching and rainfall parameters. The relationship is examined using Pearsons' correlation statistics whereas, multiple regression techniques to assess the causal relationship between the dependent and independent variables.

\section{Relationship between Mulching and Runoff, and, Soil Loss}

The aim was to examine the relationship between mulching and runoff and soil loss. In determining whether or not, there is a relationship, Pearson's correlation statistic was used.

Table 5: Relationship between Mulching on Runoff and Soil Loss

\begin{tabular}{llccc}
\hline Mulching & & Mulching & Runoff & Soil Loss \\
\hline Runoff & Pearson Correlation & -0.668 & 1 & 0.649 \\
& Sig (2-tailed) & 0.000 & & 0.000 \\
& N & 90 & 90 & 90 \\
Soil loss & Pearson Correlation & -0.601 & 0.649 & 1 \\
& Sig (2-tailed) & 0.000 & 0.000 & \\
& N & 90 & 90 & 90 \\
\hline
\end{tabular}

Source: Field Work 2016

The analysis revealed strong relationship of .0668 or $67 \%$ between mulching and runoff. This explains $67 \%$ of runoff amount in the study by mulching. While the relationship between mulching and soil loss was 0.601 or $60.1 \%$. That is, the amount of soil loss was explained by mulching $60.1 \%$ in this research, holding other factors constant. Runoff and soil loss were all significant at 0.000 which is less than 0.001 (2tailed). This means, the level of soil loss and amount of runoff recorded in the study was related to the cover percentage (mulching) on the study plots (see appendix).

\section{Relationship between Rainfall Parameters on Runoff and Soil Loss}

This work was to analyze the relationship between rainfall parameters of amount and event on the volume of soil loss and amount of runoff. From the analysis, the relationship existing between rainfall amount and event on runoff amount and volume of soil loss was weak but positive (Table 6)

Table 6: Relationship between Rainfall Parameters on Runoff and Soil Loss

\begin{tabular}{llccc}
\hline $\begin{array}{l}\text { Mulchin } \\
\text { g }\end{array}$ & & $\begin{array}{c}\text { Mulc } \\
\text { hing }\end{array}$ & Runoff & Soil Loss \\
\hline Runoff & Pearson Correlation & 0.211 & 1 & 0.649 \\
& Sig (2-tailed) & 0.28 & & 0.000 \\
& N & 90 & 90 & 90 \\
Soil loss & Pearson Correlation & 0.088 & 0.649 & 1 \\
& Sig (2-tailed) & 0.412 & 0.000 & \\
& N & 90 & 90 & 90 \\
\hline
\end{tabular}

Source: Field Work 2016

The relationship between rainfall parameters and runoff was .231 or $23.1 \%$ while the relationship between rainfall parameters and soil loss was 0.088 or $0.1 \%$. This means that, rainfall parameters of amount and event only, have a small percentage $(23.1 \%)$ on the amount of water discharge in the study, while $76.9 \%$ is not explained because of other factors. On the other hand, rainfall parameters of amount and event have a weak relationship between soil loss $(0.1 \%)$. Invariably, other factors of soil structure, texture, moisture regime, rainfall duration, 
intensity, kinetic energy of raindrop among others that was not included may explain the $99.9 \%$ remaining. What can be deduced is that, independent variables also have influence on one another. For example, the rate of mulching may influence rainfall parameters of amount and event in producing runoff or soil loss, or vice versa. It is therefore important to examine the joint contributions of these variables on runoff and soil loss at different surface treatment.

\section{Statistical Relationship between Rainfall and Runoff under Mulching.}

The relationship between the independent variables of rainfall parameters of amount and event, as well as mulching and the dependent runoff variable was examined using multiple regression analysis. A multiple regression was done on the three plots (control (Otons) and mulched treatment of 4 tons and 8 tons). The result revealed a regression coefficient of $89.2 \%$ from the ten rainstorms.

The result of the regression further revealed that the independent variables of rainfall parameters of amount and event as well as mulching had stronger regression on $2^{\text {nd }}, 7^{\text {th }}$, and $15^{\text {th }}$ August, $4^{\text {th }}, 5^{\text {th }}$ and $12^{\text {th }}$ September (see Appendixes).

The details of the regression showed that, on $2^{\text {nd }}$ August, , regression coefficient or $r$ had 0.905 or $90.5 \%$ and a coefficient of determination or $\mathrm{r}^{2}$ of 0.819 or $81.9 \%$. This means that, the amount of water discharged on the plots is explained $81.9 \%$ of the variations of the effect of rainfall parameters i.e amount and event, and mulching. This variation is further explained by ANOVA, the P. value of 0.006 less than 0.05 alpha agreed with this variation. Coefficient of variation $C . V$ revealed that, at $95 \%$ confidence level, rainfall parameters had significance level of 0.195 . This is greater than 0.05 alpha, implying, the amount of rainfall does not necessarily equate the amount of water discharge. On the other hand, the level of soil surface covered with materials i.e organic or inorganic, limit the amount of water discharge per event (or annum) of precipitation on farm fields or catchment areas. This result affirm the studies of Zhang (1997), Lal (1997) and Ghalomi (2013) whom they agreed that extreme rainfall amount do not have a corresponding effect on surface water discharge because, other factors also interplay like; surface roughness, soil structure, and, intensity and duration of rainfall will affect the volume of runoff (see Tables $7 \&$ 8).

Table 7: Combined Model Summary on Effect of Rainfall and Mulching on Runoff

\begin{tabular}{|l|l|l|l|}
\hline $\mathrm{R}$ & $\begin{array}{l}\mathrm{R} \\
\text { square }\end{array}$ & $\begin{array}{l}\text { Adjusted } \\
\mathrm{R}\end{array}$ & $\begin{array}{l}\text { Standard error } \\
\text { of the estimate }\end{array}$ \\
\hline $.905^{\mathrm{a}}$ & $0 . .819$ & $0 . .759$ & 25277.85312 \\
\hline
\end{tabular}

However, regression coefficient of $24^{\text {th }}$ August and $12^{\text {th }}$ September rainstorms revealed strong $\mathrm{r}$ and $r^{2}$ values of 0.898 and $0.807(80.7 \%)$, and, 0.909 and $0.825(82.5 \%)$ respectively. The coefficient of determination of $80.7 \%$ and $82.5 \%$ on $24^{\text {th }}$ August $\& 12^{\text {th }}$ September explained the variations in the effects of rainfall parameters and mulching on runoff. As noted before, ANOVA technique shows $0.007\left(24^{\text {th }}\right.$ August $)$ and $0.005\left(12^{\text {th }}\right.$ Sept. $)$ which is less than 0.05 alpha, indicates that, there is variation in the effect of rainfall parameters and mulching. Furthermore, C.V from $24^{\text {th }}$ August ( 0.224 on rainfall and 0.003 on mulching) and $12^{\text {th }}$ September $(0.224$ on rainfall and 0.004 on mulching) explain there is no significant effect on the amount of rainfall on runoff volume while mulching on the other hand, affect the amount of discharge with its level of cover on the earth's surface i.e plots. Holding other factors constant, rainfall amount has no significant effect on the level of runoff on plots i.e $0.224>0.05$, whereas, the level of mulch treatment has a great effect on the level of runoff with 0.003 and 0.004 as it is less than 0.05 alpha value.

\section{Combined Relationship between Rainfall Amount and Mulching on Soil Loss.}

A multiple regression was done to determine the relationship between rainfall parameters of amount and event, as well as mulching on soil loss. Like runoff, soil loss had regression coefficient of $80.1 \%$ and a coefficient of determination $65 \%$. The $r^{2}$ value of $65 \%$ explained the variations within rainfall amount and event, and mulching on soil loss holding other factors constant. Details from the result revealed that, $2^{\text {nd }} / 8$ and $4^{\text {th }} / 9$ had the highest variation $80.6 \% \& 83.3 \%$ while $26^{\text {th }}$ August, $5^{\text {th }}$ and $12^{\text {th }}$ September had weak positive variation in explaining soil loss +0.388 or $39 \%,+0.555$ or 
$56 \%$ and +0.492 or $49 \%$ respectively (see appendices).

Table 8: Combined Coefficient of Variation between rainfall and mulching on Runoff

\begin{tabular}{clllll}
\hline $\begin{array}{c}\text { Model } \\
1\end{array}$ & $\begin{array}{l}\text { Un-standardized } \\
\text { coefficients }\end{array}$ & Std Error & $\begin{array}{l}\text { Standardized } \\
\text { Coefficient Beta }\end{array}$ & $\mathbf{t}$ & sig \\
\hline Constant & -143595.709 & 158449.332 & & -0.906 & $\mathbf{0 . 4 0 0}$ \\
Rainfall & 97633.438 & 67028.030 & .253 & 1.457 & 0.195 \\
Mulching & -12917.792 & 2579.910 & -869 & -5.007 & 0.002 \\
\hline
\end{tabular}

Source: Field Work 2016

Further result from the ten rainstorms on ANOVA, four events revealed that the model is not significant, because the values are more than 0.05 alpha level; 0.106, 0.229, 0.088, and 0.131 on $24^{\text {th }}, \& 26^{\text {th }}$ August, $5^{\text {th }}$ and $12^{\text {th }}$ September respectively. On the other hand, six rainstorm events agreed with the model that it is significant because, the values are all less than 0.05 . Determining the strength of effect of the independent variables rainfall amount, event and mulching on the dependent variable soil loss, coefficient of variation was employed. From the analysis of CV $95 \%$ confidence level, only one event $\left(4^{\text {th }} / 9\right)$ failed to follow the trend $(0.031)$ on rainfall amount having significant effect on volume of soil loss in this study. The rest of nine rainstorms show that, the amount of rainfall have no significant effect on the volume of soil loss, since at $95 \%$ confidence levels are greater than 0.05 alpha value. This result conformed with the studies of Lal,(1997), and Iorkua, (2013), both agreed that, rainfall amount alone do not necessarily correspond with the amount of sediment yield, since other factors also interplay like kinetic energy of raindrop, intensity, angle of splash or raindrop, direction of wind and the nature of soil (physical, chemical, and structure present). Although, their studies were based on soil trays construction, examining different angles of slope, comparing bare and treated surfaces unlike, this study which is directly on cultivated farm fields.

On the other hand, mulching unlike rainfall revealed that, the rate of soil surface cover have simultaneous effect on sediment yield i.e soil loss. This means, the level of soil cover limit the kinetic energy of raindrop, increase the rate of infiltration, and reduce soil surface compaction, sealing and crust. For example, the analysis from this result revealed that, out of ten rainstorms, only seven rainstorms at $95 \%$ or 0.05 confidence level explains that the level of surface cover limit the rate and volume of soil loss on the plots i.e $0.003,0.010,0.008,0.009,0.046,0.010, \& 0.039$ on $2^{\text {nd }}, 7^{\text {th }}, 15^{\text {th }}, 19^{\text {th }}$, and $26^{\text {th }}$ August, $4^{\text {th }}$ and $5^{\text {th }}$ September respectively (see appendices), while three of these rainstorms do not agreed with this trend.

\section{The Implication of Mulching on Soil Erodbility}

In the course of the study, it was observed that, the rate of mulch on plots significantly changed soil characteristics. It was evident that, stability of soil on the covered surface was quite different from that of the uncovered area. Water discharge on the plots resulted to high figures from the plots that were not covered decreasing down to the highest rate of mulching (8tons). Table 4.2 shows a general trend in decrease of volume of water discharge on treated surfaces 4tons and 8tons as compared to the control plots. Again, the amount of soil loss that thus, results from runoff simultaneously is reduced. The spaces in between the planted maize as the leaves were touching each other and the root (a month and three weeks) help in the protection of soil surface on the plots by resisting the soil to the erosive forces raindrops (kinetic energy Iorkua 2013), and fluvial stress of transporting the detached particles (Lal 1997) to new site (see figure 4.4).

Furthermore, in assessing the moisture content of the soil, the reduction in volume of water discharge and concurrent soil loss explains high level of infiltration on treated plots. The level of infiltration in an area determines moisture content of that particular soil. It was observed that, in an interval of five to six days or even more, the treated surfaces were still wet i.e, $7^{\text {th }}$ to $15^{\text {th }}$ August, $26^{\text {th }}$ August to $4^{\text {th }}$ September and $5^{\text {th }}$ 
to $12^{\text {th }}$ September respectively. Although, there were some insignificant changes in variations within treated plots as compared to control. On the other hand, the dry nature of surface soil on the control plots seems to be strong. This is evidence of surface sealing, crust, and compaction which is catalyst for surface runoff and vulnerable to environmental degradation by fluvial erosion.

Microbial activities were observed to be very high in the study. The casting of earthworms were also observed and counted. The counting of earthworm casting was done in every two weeks interval. It was on record that, 4 tons rate of mulching had between numbers of 8 to 12 cast per each plot whereas, 8 tons mulch rate had 10 to 15 cast while the control was between the numbers of 3 to 5 each. Burrowing animals on the other hand like Ants, Crickets and Termites also made their footprints. Notably, at the tail end of the research period, these activities drastically reduced the level (height) of these mulching materials. The number of casting from these organisms indicates high level of soil fertility and maturity. The level of surface wash observed from the research was varied amongst plots. It was evident that, at beginning of each controlled (0 tons) plots, soil erosion was seen without using erosion pins. The amount seen from start of plots did not reach the outlet. This may be attributed to surface roughness as noted by Bradford et al (1987) been that not every soil eroded will lost out of an area completely.

\section{Conclusion}

This research work examined the analysis of surface runoff and soil loss under different mulch treatments. This study was carried out at the teaching and research farm of the College of Agronomy, Department of Soil Science (North Core), University of Agriculture, Makurdi. The field work was conducted during the rainy season with three (3) constructed and replicated experimental plots. The plots were replicated three times with $20 \mathrm{~m} \times 3 \mathrm{~m}$ and a downward outlet of $1 \mathrm{~m}(61.5 \mathrm{~m})$ adding to fifteen (15) plots. The plots were treated with dead organic mulch and planted maize. The study employed purposeful sampling technique. A total of Ninety (90) samples were purposefully collected from ten rainfall events spanning from July to September. The data were gotten through field measurement and observation to determine rainfall amount and event, as well as mulching on runoff amount and volume of soil loss. The data collected from the field were tabulated and analyzed using simple percentages and averages, correlation technique, ANOVA, C.V, multiple regression to determine if significant differences exist (at 0.05 alpha level).

From the result, it was discovered that, the amount of runoff occurred on bare-surface (control) is 138 times more than 4ton and 8tons plots put together. Also, the level of surface treatment increases so also volume of runoff decreases. Again, the amount of soil loss in this study revealed that, control plots had over $98 \%$ soil loss while less than $2 \%(1.6 \%$ and $0 \%)$ recorded on 4ton and 8 ton concentration plots respectively. The result did not revealed any simultaneous effect on amount of rainfall on runoff and soil loss as seen from figure 4.3. This study also observed that, the covered plots had higher behavior of microbial activities i.e ants, crickets, termites, rats etc as compared to uncovered plots. The findings were that, rainfall parameters of amount and event as well as mulching had significant effect on runoff, since the study revealed that rainfall and mulching explained 0.499 or $50 \%$ of the variation in the amount of runoff giving ANOVA p. value of 0.000 indicating that the model is significant. Also, rainfall parameters and mulching influence soil loss explaining weak but positive variations $37 \%$, at 0.05 alpha level (95\% confidence level), all were significant. Although, only mulching was significant (at 0.000) in affecting soil loss unlike rainfall parameters (at 0.307), which was not significant Research conducted revealed that there is significant difference in both rainfall parameters and mulching in affecting runoff amount and soil loss volume. The study also revealed that, the amount of rainfall do not correlate with the amount and volume of runoff and soil loss, whereas, the differences in rate of surface cover (mulching concentration) simultaneously affect the volume and amount of soil loss and runoff respectively. Field observation revealed that, mulching has great influence in soil formation as it limit the impact of rainfall on soil surface directly, increase infiltration capacity of the soil, improve soil temperature and increase microbial activities within the soil through decomposition by adding soil fertility. From the result, the following 
recommendations were made for purpose of emphasis: From the study, result revealed that, mulching on different levels of treatments i.e 4tons and 8tons concentration conserve surface water and soil effectively. The percentage conservation of water was $96.6 \%$ and $99.3 \%$ on 4ton and 8ton respectively. This then implies that, mulching concentration of these tons is very important since there is cheap availability on farm fields. On the other hand, soil conservation was $98.5 \%$ and $100 \%$ on 4 tons and 8 tons respectively. With this, the study strongly recommends that surface soil conservation of this concentration $(4 \mathrm{t}$ $\& 8 \mathrm{t}$ ) should be practiced with this kind of simple mixed farming. The observation made in the course of this research, on experimental plots, especially 4tons and 8tons due to dead organic mulch, activities of micro-organisms were high in trying to decompose the materials which this can add to soil fertility. Also, the level of surface soil dryness, hardness depicting soil seal, crust and compaction on control (0tons) plots were not seen on 4tons and 8tons respectively. So, practicing this kind of mulching concentration is strongly recommended. This present study only investigates rainfall parameters of amount and event on influence of runoff and soil loss. Other equal important aspects of rainfall parameters resulting to surface runoff and soil loss or sediment yield were not incorporated in this study, viz; Rainfall parameter of intensity; this is an amount of rainfall per unit time, it is an aspect of rainfall which result in stimulating the amount and rate of surface runoff and soil loss in an environment or watershed either positively or negatively. Rainfall duration; this is the period of rainfall event in a particular time. This duration also encourage positively or negatively the rate and amount of runoff and soil loss in a catchment area. The kinetic energy of raindrop; it is the striking force of raindrop on the soil surface. If the energy is high, pore spaces are easily blocked limiting infiltration and encouraging runoff subsequently soil loss, and vice versa. Again, the striking angle of raindrops which ignite soil splash. These other aspects could be studied in the area to have more comprehensive understanding on runoff responds and concurrent soil loss. The characteristics of soil particles eroded were not examined. Importantly, the textural characteristics of soil which would have provide a comprehensive knowledge on some of the variations in explaining runoff and soil loss noticed in this study, further studies should incorporate this.

\section{References}

Abaa, S.I. (2004). Origin of the Benue Trough and Economic Significance to Nigeria. $2^{\text {nd }}$ Inaugural Lecture of Benue State University, Makurdi.

Balvinder, S., G.N. Gupta, and K.G. Prasad (1988).Use of Mulches in the Establishment and Growth of Tree Species on Dry Lands. Indian Forester114:307-316.

Bradford J.M., Ferris J.E., Remley P.A. (1987) Interrill Soil Erosion Processes: I. Effect of Surface Sealing on Infiltration, Runoff, and Soil Splash Detachment, Soil Science Society of America Journal, Vol. 51, pp.1566-1571.

Bryan R.B (1969), The Relative Erodibiliy of Soils Developed in the Peak District of Derbysire. nt Geografiska Annaler, Vol. 51-A, pp.145-159.

Daura M.M (1995), Comparative Analysis of Runoff, Soil and Nutrient Loss under Different Cropping Systems. Unpublished Ph.D. Thesis, Department of Geography, University of Ibbadan, 225pp.

Eze B.E (1996), Rain Splash Detachment under Different Land Use Surfaces in a Humid Tropical Environment. Unpublished Ph.D. Thesis, Department of Geography, University of Ibadan, 226pp.

Gholami, L., Sadeghi, S.H. R., and Homaee, M. (2013): Straw Mulching Effect on Splash Eosion, Runoff and Sediment Yield from Eroded Plots, Soil Science Society of America Journal, Vol.77, pp.268-278,

Iorkua, S. A. (2013): The Effect of Slope Angle and Mulching on Splash Erosion in Tropical Humid Area. An Unpublished Ph.D Thesis, Department of Geography, University Ibadan, Ibadan Nigeria.

Iorliam A.Y., Agbede I.O. and Joel, M. (2012b).Effect of Bamboo Leaf Ash on Cement Stabilization of Makurdi Shale for use as Flexible Pavement Construction Material. American Journal of Scientific and Industrial Research Vol. 3, No. 3, p.166-174. 
Jin, K., W.M. Cornelis, D. Gabriels, M. Baert, H.J. Wu, W. Schiettecatte, D.X. Cai, S. Deneve, J.Y. Jin, R. Hartmann and G. Hofman (2009): Residue Cover and Rainfall Intensity Effects on Runoff and Soil Organic Carbon Loss. Catena, Vol. 78, No.1, pp. 81-86.

Jordán, A., L.M. Zavala and J. Gil (2010): Effects of Mulching on Soil Physical Properties and Runoff under Semi-arid Conditions in Southern Spain. Catena, Vol. 81, No. 1, pp.77-85.

Lal R. (1976b) Soil Erosion on Alfisols in Western Nigeria II: Effects of Mulch Rates. Geoderma Vol. 16, pp.377-387.

Montenegro, A.A.A., de Lima, J.L.M.P., Abrantes J.R.C.B.O. and. Santos, T.E.M (2013): Impact of Mulching on Soil and Water Conservation in Semiarid Catchments: Simulated Rainfall in the Field and in the Laboratory. Soil Science Society of America, Pp 79-85.

Nyagba J.L (1995) The Geography of Benue State in Denga D.T (1995) (ed), Benue State: The Land of Great Potentials: A Compendium. Calabar, Rapid Educational Publishers Ltd.

Smith, L. J. and W.A. Stroch (1995): Turf Herbicide Injury to Landscape Trees as influenced by Mulch. Journal of Environment and Hortiulture, Vol. 13:pp. 60-63.

Tyubee B.T. (2005), Spatial Organisation of Daily Rainfall in the Middle Belt of Nigeria. The Benue Valley Vol. 412005 Pp 69-71

Unger, P.W. and R. Jones (1981), Effect of Soil Water Content and a Growing Season Straw Mulch on Grain Sorghum. Journal of Soil Science of America, Vol. 45, No 1, pp. 129.

Uwah D.F and Iwo G.A (2011); Effectiveness of Organic Mulch on the Productivity of Maize (Zea Mays L) and Weed Growth The journal of Animal and Plant Science, Vol. 21, No 3, Pp525-530.

Wuese T.S (2013): The Effect of Selected Tillage Practices on Soil Loss in Southern Guinea Savannah Agro-Ecology of Nigeria. Unpublished M.Sc. Thesis, Department of Soil Science, University of Agriculture, Makurdi.

Zhang, X., X.L. Wang and Corte-Real, J. (1997): On the Relationships between Daily Circulation Patterns and Precipitation in Portugal. Journal of Geophysical Research, Vol. 102 NoD12, pp.1349513507. 